\title{
ENHANCING SERVICE PERSONNEL'S EMOTIONAL LABOUR TECHNIQUES: AN EMPIRICAL CASE FOR SPIRITUAL INTELLIGENCE
}

\author{
Kazeem Olanrewaju Ogunsola ${ }^{1 *}$, Rodrique Ancel ot Harvey Fontaine ${ }^{2}$, Muhammad Tahir \\ $\mathrm{Jan}^{3}$ \\ *Corresponding Author \\ ${ }^{1}$ Department of Business Administration, Kulliyyah of Economics and Management Sciences, International Islamic \\ University Malaysia, Jalan Gombak, 53100, Selangor, Malaysia, qmasjid@yahoo.com \\ ${ }^{2}$ Kulliyyah of Economics and Management Sciences, International Islamic University Malaysia, 53100, Selangor, Malaysia, \\ ridhwan_fontaine@iium.edu.my \\ ${ }^{3}$ Kulliyyah of Economics and Management Sciences, International Islamic University Malaysia, 53100, Selangor, Malaysia, \\ tahirjan@iium.edu.my
}

\begin{abstract}
The paper aims to examine the relationship between emotional labour (EL) techniques of surface acting (SA) and deep acting (DA) with spiritual intelligence (SQ). Building on Multiple Intelligence Theory (MI), 373 service personnel, mainly teachers, were drawn through a list-based simple random sampling, from 30 secondary schools around Peninsular Malaysia. Structural equation modelling (SEM) was used to test the hypotheses, and the proposed model was assessed through renowned model fit indices. Findings revealed that SQ buffers EL costs, as both SA and DA routine became positively related to SQ. Proposed model had reasonable fit indices with $\chi^{2} /$ df ratio $(1002.288 / 336)=2.983$, RMSEA $(0.078)$ and CFI $(0.931)$. Providing empirical support to the hypotheses that EL performance tends resonate well with spiritual intelligent service personnel. The adequacy of this paper's findings is vital as it cut across all Faiths. Practically, it tends to stimulate service personnel towards a higher degree of self-awareness and imbue them with the capacity to be flexible, face and transcend pain and suffering. Socially, it sustains a friendly and cordial interpersonal relationship with others (customers). Policy wise, it informs organizations to re-align HR strategies to capture 'Type B' personalities. Theoretically, it stirs more research on SQ as it affects service personnel's organizational behaviours. The paper is cross-sectional and limited to one group of service personnel (teachers). Future study may consider other groups to ascertain the generalizability of these findings. While augmenting body of knowledge on organizational behaviour, the study is pioneered as the first to propose SQ to buffer EL costs, in order to enhance SA and DA techniques.
\end{abstract}

Keywords: Spiritual intelligence (SQ), emotional labour (EL), surface acting (SA), deep acting (DA), service personnel, task performance

Received

September 7, 2020
Revised

September 30, 2020
Accepted

September 30, 2020
Published

September 30, 2020

\section{INTRODUCTION}

Emotional labour is a critical issue for service-based organisations. Since its introduction over three decades ago (Hochschild,1983), research has looked at its advantages and disadvantages for organisations and service personnel (Andrews et al., 2016; Cropanzano et al., 2003). To date, there is very little research on the relationship between both surface acting (SA) and deep acting (DA) techniques of emotional labour (EL) and spiritual intelligence (SQ) of service personnel. Service personnel in this context are group of front line employees considered as "face of the organization" who must reveal certain emotions and suppress others" (Walsh \& Bartikowski, 2013 p.46).

This is a significant omission in literature considering that, in a service-based organization, customers will perceive the quality of the organisation based on the service 
interaction with front-line employees (Gabriel et al., 2015; Richard et al., 2016; Ruppel et al., 2013). So, service personnel who learn to manage their emotions become better employees (Christoforou \& Ashforth, 2015; Liu \& Cho, 2018; Richard \& Converse, 2016). This omission is also striking given the growing concern for employees' well-being (Fry et al., 2016). Brotheridge and Lee (2003 p. 366) argued that "EL is a multidimensional construct that could have differential impact on employees' outcomes".

Previous literature documented that prolonged SA and DA techniques have been linked with a number of negative outcomes (Firuzjaeyan et al., 2015; Hofmann \& Stokburger-Sauer, 2017), such as denial of authentic self and poor self-esteem (Santos et al., 2015), and mental health issues (Kaur \& Malodia, 2017). Possibly, because service jobs require that employees interact with all kinds people, including those who are courteous, disorderly, or rude (Ling, 2017; Richard et al., 2016). Irrespective of the person, employees need to control their emotional disposition, maintain calmness and provide proficient interactive service (Hochschild, 1983; 2012). If they do not, the consequences can include getting query letter, suspension, transfer, dismissal, revocation of licence, lawsuits and so forth.

In practice though, putting an end to SA and DA techniques is seemingly unlikely by service-based organizations (Putnam \& Mumby, 1993). Against this backdrop, scholars have found that spiritual intelligence can have a positive impact on emotional state, thoughts, wellbeing and behaviours at work (Conor et al., 2011; Fontaine, 2018; Giacalone \& Jurkiewicz, 2010; Mahmood et al., 2018; Osman-Gani \& Hassan, 2018; Sisk, 2015). This potentially brings spiritual intelligence into the field of emotional labour.

\section{LITERATURE REVIEW}

\section{Human Emotions}

Emotions are expression of distinctive feelings and dispositions, drawn upon perception, occurring through the process of internal bodily signals (Critchley \& Garfinkel, 2017), usually directed towards someone (e.g., co-worker, supervisor or customers) or something (e.g., unethical attitude, query letter or job promotion) (Schermerhorn et al., 2011; Wang et al., 2017). Contemporary psychologists and philosophers grouped emotions into six basic types - anger, fear, sadness, happiness, disgust and surprise (Weiss \& Cropanzano, 1996). Most service jobs require suppressing negative emotions (e.g., anger) for positive emotions (e.g., joy), regardless of the emotional state of service personnel (Gabriel et al., 2015). Hence, their engagement in EL process.

\section{Emotional Labour}

Emotional labour is "the process of managing feelings and expression to fulfil the emotional requirements of a job, such that displayed emotion will enhance expected performance" Hochschild (1983 p. 7). Such emotional requirements would normally consist of "behavioural expectations about which emotions ought to be expressed and which ought to be hidden" (Rafaeli \& Sutton, 1987 p.27). So, EL serves as a form of diplomatic route between organizations' expected emotions and organizational outcomes such as productivity, improved sales, enhanced performance, customer retention and so forth. 
Some organizations use handbook, personal briefings, billboards or classes; others provide staff training on feelings allowable to be expressed and which to be supressed (Christoforou \& Ashforth, 2015; Diefendorff et al., 2011; Hochschild, 2012; Liu \& Cho, 2018) to enhance good customer experiences and boost service performances. Against this backdrop, researchers have attempted to offer different definitions to the concept of emotional labour. Table 1 gives a summary view of some definitions on emotional labour.

Table 1: Summary View of Some Definitions on Emotional Labour

\begin{tabular}{ll}
\hline Authors & Definitions \\
\hline $\begin{array}{l}\text { Brotheridge and Lee } \\
(2003 \text { p.365) }\end{array}$ & $\begin{array}{l}\text { Employees' effort to regulate their emotional display in an attempt to meet } \\
\text { organizationally based expectations specific to their roles. }\end{array}$ \\
$\begin{array}{l}\text { Prentice (2014 p. } \\
188)\end{array}$ & $\begin{array}{l}\text { As managing emotions through surface or deep acting by following organisational } \\
\text { display rules in return for a wage. }\end{array}$ \\
$\begin{array}{l}\text { Gabriel et al., (2015 } \\
\text { p. } 863 \text { ) }\end{array}$ & $\begin{array}{l}\text { The regulation of emotions to conform to display rules, and actual emotional expressions } \\
\text { to customers. }\end{array}$ \\
$\begin{array}{l}\text { Richard et al., (2016 } \\
\text { p.118) }\end{array}$ & $\begin{array}{l}\text { The extent to which employees regulate their emotional displays at work in response to } \\
\text { display rules or standards for appropriate emotional expression at work. }\end{array}$ \\
$\begin{array}{l}\text { Zou and Dahling, } \\
2017 \text { p.1) }\end{array}$ & $\begin{array}{l}\text { This is a process of managing emotions as part of a work role. } \\
\text { H. J. Lee (2018 p.4) }\end{array}$ \\
$\begin{array}{l}\text { Occurs as service workers manage their own emotions (and especially the facial and } \\
\text { bodily expressions of those emotions) to comply with organizational rules and to } \\
\text { promote customer satisfaction. }\end{array}$ \\
$\begin{array}{l}\text { Current Authors (n. } \\
\text { d) }\end{array}$
\end{tabular}

Source: (Authors' Compilation)

With the foregoing discussion, irrespective of what situation presents itself, service personnel would usually be expected to follow the HAND (Have A Nice Day) rule by simple taking a deep breathe, look the customers in the eyes and offer a generous smile (Brotheridge \& Lee, 2003; Mann, 1997). So, to induce emotions that are absent and must be expressed (Becker \& Cropanzano, 2015), engagement in EL techniques is necessarily required (Hagenauer \& Volet, 2014).

\section{Emotional Labour Techniques Surface Acting (SA)}

Surface acting is otherwise referred to as fake or facade acting (Andrews et al., 2016) or the "ability to maintain emotional display even when felt emotions are different" (Zapf, 2002 p.246). For instance, an expression of pleasantry by frontline service personnel may not necessarily mean they cherish a customer / client. Studies have proven that people from time to time presents facial expressions that doesn't echo their felt emotions (Mann, 1997; Mark, 2010). So, surfacing acting is simply about evoking emotional display that doesn't represent their feelings or even when no emotion is felt (Okabe, 2020; Walsh et al., 2019).

\footnotetext{
${ }^{1}$ Operational definition by authors of the current paper
} 


\section{Deep Acting (DA)}

Deep acting relates to "changing one's feelings regarding an interaction so that emotional expressions naturally fall in line with expectations" (Grandey et al., 2013 p. 207). So, rather than mere faking unfelt feelings, service personnel may actively alter inner feelings to express the emotion they wish to display (Nauman et al., 2019; Pillay et al., 2019). Possibly, by either "directly exhorting the feelings or indirectly experiencing it through trained imagination" (Hochschild, 1983 p. 38). Then, service personnel would have profoundly manipulated the entire emotional states (Mann \& Cowburn, 2005; Walsh \& Bartikowski, 2013; Yu-Shan \& Tom, 2016) to seamlessly feel, think and act organizationally desired emotions (Addison, 2017; Schirmer \& Adolphs, 2017).

\section{Dysfunctions of Emotional Labour (EL) Techniques}

Though, conforming to SA and DA techniques can ease employees-clients' interaction (Richard \& Converse, 2016; Roth et al., 2014), aid task accomplishment (Diefendorff et al., 201; Yin et al., 2017), encourage customer retention (Chen et al., 2012) or boost business success (Zou \& Dahling, 2017). Still, they can be "psychologically demanding" (Becker and Cropanzano, 2015 p. 198) for service personnel. Organizational expectations in this regard are in contrast to other jobs whose labour requirements are fixated on physical and mental capability, like factory machine operators. Service personnel require additional labour (e.g., emotion) to augment both physical and mental labour for effective service delivery. For this reason, researchers (e.g., Gabriel et al., 2015; Grandey \& Sayre, 2019; Prentice, 2014; Richard et al., 2016) argued that service personal is a form of labour.

In this connection, fulfilling the emotional requirements of a job presumes that the "acts of emotion management are not simply a private affair" (Hochschild, 1983 p.18) but that of the organization. Researchers (e.g., Grandey \& Sayre, 2019; Ogunsola, Fontaine, \& Jan, 2020) assent that, at this instance, emotion management is presumed to have been commoditised. Perhaps, in exchange for service payment, customers' satisfaction, increased revenue to service companies, retention of customers / clients and so forth.

So, if SA and DA techniques are for "exchange-value, exploitative, and alienating" (Kwok, 2011 p.1315), then, they may portend some costs to the actors the actors (i.e., service personnel). These costs may be categorised into three: health, performance cost and socialeconomic costs.

\section{Health Cost}

Service personnel are susceptible to experience emotional imbalance (Richard \& Converse, 2016), which often increases their risk of emotive dissonance (Lee, 2017). Possibly, because EL techniques are known to alter expressive behaviours (outward emotions), but most times, not the inner self (Grandey et al., 2015; Mann \& Cowburn, 2005). Emotive dissonance is the "persistent structural discrepancy between displayed emotions and what is felt" (Yagil, 2015 p.158).

Faking or inducing unfelt feelings commonly lead to self-denial, poor self-esteem or estrangement from self (Dunbar \& Baker, 2014; Prentice, 2014; Rafeali, 1987; Yin et al., 2017). These are health-risk related problems that can cause depression, exhaustion and mental distress (Indregard et al, 2018) in service personnel. Other studies mentioned that these forms of denial causes certain "pernicious psychological effects" (Ashforth \& Humphrey, 1993 p.89) which are detrimental to wellbeing (Kim \& Han, 2009). 


\section{Performance Cost}

Rather than facilitating task performance, the techniques may become counter-productive (Kinman et al., 2011). Threatening service personnel's psychological resources, particularly, when work demands exceed their coping mechanisms (Chen et al., 2012; Karatepe \& Olugbade, 2009). For instance, when drained emotionally, service performance can become reduced or the employees become redundant (Y. H. Lee, 2017; Yilmaz et al., 2015). Mostly, this prompt service personnel to sometimes seek leave of absence, opt for voluntary resignation, arbitrary absenteeism, and so on (Mafukata \& Mudau, 2016; Mariesa \& Rockoff, 2012).

\section{Social-Economic Costs}

When quantified, SA and DA are usually undercompensated (Hülsheger et al., 2015) because acting cheery, pleasant or smiling are intrinsically motivated performances at the expanse of the actors (service personnel). Often, this could lead to reduced sense of belonginess. Grandey et al., (2015) argued that sometimes, they are faced with interactional injustice (i.e., disrespected by customers), and attempt to revolt might lead to punitive measures such as job loss, pay cut, reprimand, suspension or dismissal (Dahling, 2016; Hagenauer \& Volet, 2014; Richard et al., 2016; Yagil, 2015).

Taken together, it can be argued that SA and DA deplete service personnel psychological resources (Kinman et al., 2011), affects their wellness (Mishra \& Kumar, 2016) and consequently, hinders optimal performance. Ironically, fear of being chastised or mortified makes the acts never-ending. Besides, organizations consider the acts as beneficial to bottom lines. To this end, considering variables like spiritual intelligence may tend to buffer SA and DA costs, and complement their performance by service personnel.

\section{Spiritual Intelligence}

Consideration for "spiritual intelligence may have stemmed out from earlier claims for existential intelligence" (King 2008 p. 30). Based on MI theory, Gardner (1993, 1995) argued for "existential intelligence as the domain of human intelligence" (i.e., the brain portion) responsible for solving problems with spiritual instincts. Suggesting that SQ relates to the set of skills involving the use of collective values and intuition to understand others and the world around them (Nasel, 2004; Sisk, 2015; Vaughan, 2002).

Researchers offered different definitions for SQ (see, Bhullar, 2015; Emmons, 2000b; King, 2008; Mahmood et al., 2018; Osman-Gani et al., 2017; Sisk, 2015; Zohar \& Marshall, 2000). Concisely, Fontaine (2018) defined SQ as "harnessing spiritual resources to solve problems (p. 2). Hence, it is ability to behave with compassion and wisdom while maintaining inner and outer peace (equanimity) regardless of the circumstances (Wigglesworth, 2006). This signals that SQ is an intelligence of the soul, which service personnel may adopt to nourish the inner self, in order to develop a deep sense of meaning towards environmental exigencies (Awais et al., 2015; Kumari \& Chahal, 2017; Ogunsola et al., 2020a; Soha et al., 2016).

Emmons (2000a) posit that SQ represents a "passion for the infinite" (p. 4), whose inspiration is unparallel to any other form of human motivation for goals achievement (Khaliq \& Ogunsola, 2011; King \& DeCicco, 2009; Osman-Gani \& Hassan, 2018). Such 
passion aids personal search for meaning, purpose, wholeness and the realization of the core of human existence, which results in both psychological and physical wellness (Djafri \& Noordin, 2017; Fashi, 2017; Milliman \& Bradley-geist, 2017; Naik \& Jabeen, 2019). So, for service personnel, SQ may better buffers EL infinite costs and reinvigorate in them a better performance of SA and DA.

In Burrow's (2005 p. 78) remarks, SQ components are transformative in nature, such that, they "shift individuals from a state of acting from lower motivations (e.g. greed, anger, fear and self-assertion) to one of an acting, from higher motivations (e.g. cooperation, higher service, exploration)." The current study used SISRI-24 components to profile the respondents. For SISR-24 detailed review, see King and DeCicco's (2009).

\section{Emotional Labour Costs and Spiritual Intelligence}

There are indications that using coping mechanisms may cushion EL costs (Faribors et al., 2010; M. J. Kim \& Han, 2009) (Jung and Yoon (2016), hence, proposing SQ is not confounding for service personnel. SQ has been applied in work setting as mechanism to motivate employees' commitment (Kulshrestha \& Singhal, 2017, Upadhyay, 2017)) and provide non-religious atmosphere to address workplace-related issues (George, 2006; Roof et al., 2017).

The study of Rahman and Shah (2015) revealed that SQ plays an effective mediating role in demanding jobs such that it stimulates employees towards spiritual path, which tends to help them cope with painful circumstances, by re-aligning their perception beyond materialism. Baharuddin and Ismail (2015) argued that SQ provide proficient and skilful way of understanding and applying reasonable knowledge to manipulate events towards psychological and physical well-being. Suggesting that SQ is capable of pulling employees through ego, pain and suffering associated with task engagement (Ogunsola, 2018; Othman \& Abas, 2017). Thereby, would lead to minimal or no emotion-related costs.

In other remarks, several dimensions of SQ when integrated into the work practice (e.g., SA \& DA) can greatly benefit employees in terms of emotional stability, personal wellbeing, creativity, organizational harmony, and long-term business relationship (e.g., job security). These benefits are ultimate values and are optimally important for human development (Bhullar, 2015; Butts, 1999; Vaughan, 2002). In this connection, Ramachandran (2017) established a positive link between service workers effectiveness and spiritual intelligence. (Yahyazadeh \& Fatemeh, 2012) found a significant positive relationship between job fulfilment and spiritual intelligence

Keeping the foregoing discussion in perspective, (Emmons, 2000a) posit that SQ has been "associated with a wide variety of success in living (real) life such as physical health, psychological well-being, marital satisfaction and stability" (p. 4). So, it may play a better role in guiding service personnel reasoning, moral, thoughts, emotions, and pro-social behaviours. The current study seeks to explore some of these possibilities. Therefore, it was hypothesized that:

H1: Surface acting relates significantly positive with spiritual intelligence

$H 2$ : Deep acting relates significantly positive with spiritual intelligence. 


\section{METHOD}

\section{Study Participants}

A group of service personnel, mainly teachers in the Peninsular Malaysia, were profiled. Through a list-based simple random sampling technique, 30 private secondary schools were randomly selected using research randomizer software. Apart from the initial covering letter, the researchers personally met with the school heads to brief them about the purpose of the study and the procedures for the survey.

\section{Sample Size}

15 teachers were randomly selected from each of the schools. Hence, 450 teachers were expected to respond to the survey questionnaire. Researchers (e.g., Frost et al., 2007; Hair et al., 2010; Tsang et al., 2017) recommended at least five times the number of items in a questionnaire. 33 items were being scaled. Therefore, the adequacy of the sample size is appropriate for statistical analysis.

\section{Measure (instruments)}

SA and DA techniques: Brotheridge and Lee's (2003) Emotional labour scale (ELS) with 3 items each for SA and DA was adapted. To justify the rule of thumb, which specify at least four items for construct (Hair, et al., 2010), relevant items were sourced from Näring et al., (2007) D-QEL ${ }^{2}$ scale. Bringing SA and DA to 5 and 4 items respectively, anchored on a Likert-type scale of $(1=$ 'never' and $5=$ 'always'). Item example include: "I pretend to have the emotions that I am not actually feelings".

Spiritual Intelligence: King and DeCicco's (2009) Spiritual Intelligence Self-Report Inventory (SISRI-24) items was adapted. It is tapped on a five-point Likert-type scale of $(0=$ ' $n o t$ at all true of $m e$ ' and $4=$ 'completely true of $m e$ ') to measure various behaviours, thought processes and mental characteristics of individuals. Sub-divided into 4 components: Critical Existential Thinking (CET - 7 items), Personal Meaning Production (PMP - 5 items), Transcendental Awareness (TA - 7 items) and Conscious State Expansion (CSE - 5 items). Item example include: "My ability to find meaning and purpose in life helps me adapt to stressful situations".

\section{Data Collection}

For confidentiality in data collection, survey instrument was administered electronically through Google forms. Antunes et al., (2017) argued that such means "guaranteed informed consent and data confidentiality" (p.5). Besides, "more reliable data are likely to result since the respondents can go back and forth, and easily change a response." Sekaran (2003 p. 250). The data were collected between May and August 2019.

\section{Statistical Analysis}

IBM SPSS 24.0 software was used for demography frequencies and EFA. AMOS 24.0 software was used for CFA data validation and SEM hypotheses testing.

\footnotetext{
${ }^{2}$ D-QEL : Dutch Questionnaire on Emotional Labour 


\section{RESULT}

\section{Response Rate}

From 450 expected responses, 35 respondents participated in the pilot study instrument adaptation stage. Main study had 415 participants, out of which 389 responses were received, giving a response rate of $93.74 \%$. 16 responses were invalidated with respect to Ron et al., (2015) recommendations. As a result, only a total valid 373 usable responses were finally analysed, giving a usable response rate of $89.88 \%$. The high response rate was due to several follow-up measures (e.g., phone calls, emails, visitations). Besides, prior to beginning the survey, consultations were made with the heads of each school to pre-inform them on the intent of the survey. The convenience of the responding to an electronic questionnaire also contributed to the high response rate.

\section{Social - Demographic Characteristics (Main Study)}

Participants are mostly aged between 30 and 45 years $(M=2.35 ; \mathrm{SD}=1.02)$. With respects of male, $52(14.0 \%)$ and 167 (44.8\%) females have master's and bachelor's degree respectively, $122(32.7 \%)$ female have spent over 10 years in the teaching profession, while $176(47.2 \%)$ were married. The social-demographic table (not shown due to space) demonstrates an unequal representation of gender as teachers. It can be inferred that there are more female teachers than their male counterpart. This outcome is not confounding given Ministry of Education (2018 p. 26) ${ }^{3}$ report which revealed that there are more females than males in the Malaysian education system generally.

\section{Questionnaire Characteristics}

From Table 2, the aggregate average score shows that respondents from time to time practice $\mathrm{SA}(M=2.57 ; S D=1.26)$ and periodically use DA $(M=3.16 ; S D=1.12)$.

\begin{tabular}{lcccc}
\multicolumn{5}{l}{ Table 2: Average Mean, Standard Deviations and Reliability } \\
\hline Constructs & Items & Mean & SD & Alpha \\
\hline Surface Acting (SA) & 5 & 2.57 & 1.26 & 0.904 \\
Deep Acting (DA) & 4 & 3.16 & 1.12 & 0.807 \\
Spiritual Intelligence (SQ) & 24 & 3.05 & 0.87 & 0.929 \\
\hline
\end{tabular}

Source: SPSS Output Table (2020).

The internal reliability scores for each construct suggested existence of a strong internal consistency amongst all questionnaire items. Hence, each item actually measures what it intends to measure. Values of skewness and kurtosis (not shown here due to space) revealed that most questionnaire items fell within the acceptable value range of $z= \pm 1.96(p<0.05)$ (Pallant, 2007). Supporting that data are normally distributed.

\footnotetext{
${ }^{3}$ Education Planning and Research Division. Private Education Division, Ministry of Education (2018, January 31). Retrieved from: https://www.moe.gov.my/index.php/menumedia/mediacetak/penerbitan/terbitan/buku-informasi/1587-quick-facts-2018-malaysia-educational-statistics-1/file
} 


\section{Psychometric validation report:}

\section{Exploratory Factor Analysis (EFA):}

Because all constructs were adapted, they were subjected to principal component analysis (PCA). Prior to performing PCA, the suitability of data for factor analysis was assessed. Inspection of correlation matrix revealed the presence of coefficients 0.3 and above. The Kaiser-Meyer-Oklin value was 0.877 and 0.890 for EL techniques and SQ respectively, exceeding the recommended value 0.6 (Kaiser, 1974), and Bartlett's Test of Sphericity ( $p<$ 0.05) reached statistical significance (Bartlett, 1954; Tabachnick \& Fidell, 2007), supporting the factorability of the correlation matrix. The adequacy of the data was equally proven with items having communalities values above recommended 0.3 threshold (Antunes et al., 2017; Pallant, 2007).

Varimax normalised rotated component matrix retained a two-factor solution for EL techniques: SA -5 items $(\alpha=0.94)$ and DA -4 items $(\alpha=80)$. SQ maintained its four-factor solution but with 20 items: CET -6 items $(\alpha=0.84)$, PMP -5 items $(\alpha=0.83)$, TA -5 items $(\alpha=84)$ and CSE -4 items $(\alpha=0.73)$. The factored solution demonstrated acceptable measurement properties (Guillemin et al., 1993; Nunnally, 1978). Supporting further statistical engagement (Cronbach, 1951).

\section{Confirmatory Factor Analysis (CFA)}

Validation of the factored solution measurement model through Maximum Likelihood Method (Bentler, 1983; Zainudin, 2014), using renowned fit indices revealed $\chi^{2} / d f$ ratio $(722.260 / 335)=2.156$, RMSEA $(0.071)$ and CFI (0.939). Results provided evidence for a reasonable good model fit (Browne \& Cudeck, 1993; Hair et al., 2010; Marsh \& Hocevar, 1985).

Table 3: Reliability, Validity and Pearson's Bivariate Correlation

\begin{tabular}{|c|c|c|c|c|c|c|}
\hline & CR & AVE & $(\alpha)$ & $\mathbf{S A}$ & DA & SQ \\
\hline SA & 0.92 & 0.70 & 0.94 & 1 & $0.28 * *$ & $0.15^{* *}$ \\
\hline DA & 0.91 & 0.71 & 0.80 & $0.53 *$ & 1 & $0.47 * *$ \\
\hline SQ & 0.95 & 0.52 & 0.92 & $0.39 *$ & $0.69 *$ & 1 \\
\hline \multirow{4}{*}{\multicolumn{3}{|c|}{$\begin{array}{l}\text { Construct Reliability }(\mathrm{CR}) \\
\text { Average Variance Extracted (AVE) } \\
\text { Cronbach's Alpha }(\alpha)\end{array}$}} & \multicolumn{2}{|c|}{ Threshold } & \multicolumn{2}{|c|}{ Remarks } \\
\hline & & & \multicolumn{2}{|c|}{$\mathrm{CR} \geq 0.70$} & \multicolumn{2}{|c|}{ Supported } \\
\hline & & & \multicolumn{2}{|c|}{$A V E>0.50$} & \multicolumn{2}{|c|}{ Supported } \\
\hline & & & \multicolumn{2}{|c|}{$\alpha>0.60$} & \multicolumn{2}{|c|}{ Supported } \\
\hline \multirow{2}{*}{\multicolumn{3}{|c|}{ Convergent Validity }} & \multicolumn{2}{|c|}{$\overline{\mathrm{CR}}>\mathrm{AVE}$} & \multicolumn{2}{|c|}{ Supported } \\
\hline & & & \multicolumn{2}{|c|}{$\mathrm{MSV}<\mathrm{AVE}$} & \multicolumn{2}{|c|}{ Supported } \\
\hline
\end{tabular}

Significance Level: $* 0.01(2$-tailed $)=$ correlation estimates among constructs.

$* *$ Maximum Shared Variance $(M S V)=$ values above the diagonal are squared correlations.

$\mathrm{SA}=$ surface acting, $\mathrm{DA}=$ deep acting, $\mathrm{SQ}=$ spiritual intelligence.

Examination of the model construct validity through convergent validity, discriminate validity, construct (or composite) reliability and average variance extracted (AVE), also supported the proposed (See Table 3). Standardised loadings were above 0.5 and $\leq 0.94$. All values are within stipulated acceptable ranges to support construct validity (Byrne, 2010; Kline, 2011; Schumacker \& Lomax, 2012). 


\section{Structural Equation modelling (SEM)}

Having established the construct validity, the structural model was assessed in order to provide empirical justifications for its hypotheses. Renowned fit indices yielded good fit indices with $\chi^{2} / d f$ ratio $(1002.288 / 336)=2.983$, RMSEA (0.078) and CFI (0.931). All indices fulfilled the recommended thresholds (Byrne, 2010; Hair et al., 2010; Kline, 2011), indicating that the hypothesized model represented the sampled population.

From Table 3, all constructs correlated positively with each other at SA and SQ ( $r=$ $0.39)$, also, DA $(r=0.69)$. Parameters estimates of the relationship between these constructs is that SA $\left(H_{1}: \beta=0.38, p<0.05\right)$ and DA $\left(H_{2}: \beta=0.46, p<0.05\right)$ have positive significant relationship with SQ. Such that a spirited service personnel tends to cope well EL cost and performs SA and DA techniques effectively. Therefore, all proposed hypotheses are accepted.

\section{DISCUSSION}

This study has examined the relationship between SA, DA and SQ. Spiritual intelligence was proposed as a remedy to buffer EL costs, in order to enhance effective compliance with SA and DA techniques. So, the hypothesized model fitted the data collected. In general, SQ is used to denote intelligence capacity that integrates the functions of IQ (i.e., intelligence quotient for logical and reasoning) (Upadhyay, 2017) and EQ (i.e., emotional intelligence which helps to interact with people) (Anwar et al., 2017) to achieve superior functions such as maintaining inner balance with life realities (Mamman \& Zakaria, 2016; Ramachandaran et al., 2017). This suggests that spiritual intelligence "is the central and most fundamental of all intelligences, because it becomes the source of guidance for the others" (Covey, 2004 p.53).

The findings of the study are consistent with earlier study which found that SQ is a better management of work ethics and behaviour among employees (Fontaine, 2018). Upadhyay (2017) argued that SQ relates with higher performance. Vaughan's (2002) equally discussed that SQ is a path that leads from 'fear and defensiveness' to 'love and compassion' and from 'ignorance and confusion' to 'wisdom and understanding'. This implies that, spiritual intelligent service personnel tend to cushion fear associated with hardship (EL costs) by confronting them with patience. Thus, building in them a greater sense of commitment, integrity, and empathy towards things around them (people or environment).

In other studies (e.g., Baharuddin \& Ismail, 2015; Bhatti et al., 2016; Osman-Gani \& Hassan, 2018; Pant \& Srivastava, 2017), SQ was linked to a proficient and skilful way of understanding and applying reasonable knowledge to manipulate events towards psychological and physical well-being. Therefore, it tends to serve as shield in resisting work-related challenges arising such as EL costs. The study of Houston (2014) found that SQ influences employees' interpersonal knowledge of business policy (display rules) and interaction with colleagues and customers.

Suggesting that service personnel imbued with components of SQ (see, King and DeCicco 1999) tends to cope with EL exigencies. The components provide service personnel with four forms of well-being (Fry et al., 2016; Ghadi, 2017). They are emotional, psychological, social and spiritual well-being. Maslow (1943) argued that once the needs of employees are met, they tend to display their full commitment to work. So, taken together, the results of the present hypothesized model support that SQ tends to buffer EL costs, such 
that it enhances the performance of SA and DA techniques with minimal or no effects on the actors (i.e., service personnel).

\section{CONCLUSION}

The current study investigated the role of SQ as a variable necessarily needed by service personnel to buffer EL costs in order to put up the techniques of SA and DA effectively. SQ as discussed, is a multi-dimensional construct, which seeks to improve the wellbeing and role functioning of employees. SQ brings into fusion multiple intelligences; physical intelligence - (PQ for the body), intelligence quotient (IQ for cognitive reasoning); emotional Intelligence (EQ for emotional feelings) and spiritual intelligence (SQ for soul transcendence); in order to withstand workplace-customers' inequities. So, SQ is an intelligent consent under the sphere of faith, thrusting the sincerity to engage in charity work under the domain of morality.

\section{Implication}

SQ is posited as a universal variable which cuts across all faiths. Findings are promising, such that, theoretically, the study would stir more research on SQ as it affects service personnel's organizational behaviours such as workplace deviance, turnover intention, job satisfaction and so forth. Practically, spirited service personnel tend to have a higher degree of self-awareness, imbued with the capacity to be flexible, face and transcend pain and suffering. By, implication, they are able to come to terms that SA and DA techniques are for greater benefits beyond pay cheque. Policy wise, organizations may better re-align their HR strategies to capture more of personalities with 'Type B' virtues (e.g., empathy) within the workforce to enhance their bottom lines. Organizations may also have to include spiritual training programmes within their HR practices.

\section{Limitations and Future Areas of Research}

Besides the study being cross-sectional, it is limited by the sampled population. Teachers are the only group of service personnel examined. Subsequent study may include other service jobs to determine if the study outcome is generalizable. Also, the moderating role of personality may be examined to see if such influences SQ.

\section{REFERENCES}

Addison, M. (2017). Overcoming Arlie Hochschild's concepts of the 'real' and 'false' self by drawing on Pierre Bourdieu's concept of habitus. Emotion, Space and Society, 23, 915. https://doi.org/10.1016/j.emospa.2017.01.003

Andrews, M. C., Kacmar, K. M., \& Valle, M. (2016). Surface acting as a mediator between personality and attitudes. Journal of Managerial Psychology, 31(8), 1265-1279. https://doi.org/10.1108/JMP-11-2015-0414

Antunes, R. R., Silva, A. P., \& Oliveira, J. (2017). Spiritual Intelligence Self-Assessment Inventory: Psychometric properties of the Portuguese version of SISRI-24. Journal of Religion, Spirituality and Aging, 30(1), 12-24. https://doi.org/10.1080/15528030.2017.1324350

Anwar, M. A., Osman-Gani, A. M., Fontaine, R., \& Rahman, M. S. (2017). Assessing organizational citizenship behaviour through constructing emotional intelligence. AsiaPacific Journal of Business Administration, 9(2), 105-117. 
https://doi.org/10.1108/APJBA-05-2016-0049

Ashforth, B. E., \& Humphrey, R. H. (1993). Emotional labor in service roles: the influence of identity. Academy of Management Review, 18(1), 88-115.

Awais, M., Malik, M. S., \& Qaisar, A. (2015). A review: The job satisfaction act as mediator between spiritual intelligence and organizational commitment. International Review of Management and Marketing, 5(4), 203-210.

Baharuddin, E. Bin, \& Ismail, Z. B. (2015). 7 Domains of spiritual intelligence from Islamic perspective. Procedia - Social and Behavioral Sciences, 211(September), 568-577. https://doi.org/10.1016/j.sbspro.2015.11.075

Barber, L. K., Grawitch, M. J., Carson, R. L., \& Tsouloupas, C. N. (2011). Costs and benefits of supportive versus disciplinary emotion regulation strategies in teachers. Stress and Health, 27, 173-187. https://doi.org/10.1002/smi.1357

Bartlett, M. S. (1954). A Note on the multiplying factors for various Chi Square approximations. Journal of the Royal Statistical Society, 16, 296-298.

Becker, W. J., \& Cropanzano, R. (2015). Chapter 8 Display rules and emotional labor within work teams. In In Research on Emotion in Organizations (Vol. 7, pp. 197-223). Emerald Group Publishing Ltd. https://doi.org/10.1108/S1746-9791(2011)0000007013

Bentler, P. M. (1983). Simultaneous equation sysyems as momnet structure models - With an Introduction to Latent Variable Models. Journal of Econometrics, 22, 13-42.

Bhatti, O. K., Alam, M. A., Hassan, A., \& Sulaiman, M. (2016). Islamic spirituality and social responsibility in curtailing the workplace deviance. Humanomics, 32(4), 405-417. https://doi.org/10.1108/H-03-2016-0022

Bhullar, A. (2015). The growth of spiritual intelligence. Indian Journal of Educational Studies : An Interdisciplinary Journal, 2(1), 122-131.

Brotheridge, C. M., \& Lee, R. T. (2003). Development and validation of the hospitality emotional labour scale. Journal of Occupational and Organizational Psychology, 76, $365-379$.

Browne, M. W., \& Cudeck, R. (1993). Alternative ways of accessing model fit. In K. A. Bollen \& J. S. Long (Eds.), Testing structural equation models (pp. 136-162). Newbury Park, CA: Sage.

Burrows, L. (2005). SQ: Connecting with our Spiritual Intelligence. Gifted and Talented International, 20(2), 78-80. https://doi.org/10.1080/15332276.2005.11673456

Butts, D. (1999). Spirituality at work: an overview. Journal of Organizational Change Management, 12(4), 328-332. https://doi.org/10.1108/09534819910282162

Byrne, B. M. (2010). Structural equation modeling with AMOS: Basic concepts, applications and programming. New York, NY: Taylor and Francis Group LLC.

Chen, Z., Sun, H., Lam, W., Hu, Q., Huo, Y., \& Zhong, J. A. (2012). Chinese hotel employees in the smiling masks : roles of job satisfaction, burnout, and supervisory support in relationships between emotional labor and performance. The International Journal of Human Resource Management, 23(4), 826-845.

Christoforou, P. S., \& Ashforth, B. E. (2015). Revisiting the debate on the relationship between display rules and performance: considering the explicitness of display rules. Journal of Applied Psychology, 100(1), 249-261.

Conor, J. B., Dana, M. M., \& Jason, J. D. (2011). Spirituality, religion, and emotional labor in 
the workplace. Journal of Management, Spirituality \& Religion, 8(4), 299-315.

Covey, S. (2004). The 8th Habit: From Effectiveness to Greatness. Simon and Schuster.

Critchley, H. D., \& Garfinkel, S. N. (2017). Interoception and emotion. Current Opinion in Psychology, 17, 7-14. https://doi.org/10.1016/j.copsyc.2017.04.020

Cronbach, L. J. (1951). Coefficient alpha and the internal structure of tests. Psychometrika, 16(3), 297-334.

Cropanzano, R., Rupp, D. E., \& Bryne, Z. S. (2003). The relationship of emotional exhaustion to work attitudes, job performance, and organizational citizenship behaviors. Journal of Applied Psychology, 88(1), 160-169. https://doi.org/10.1037/00219010.88.1.160

Dahling, J. J. (2016). Exhausted, mistreated or indifferent? Explaining deviance from emotional display rules at work rules. European Journal of Work and Organizational Psychology, 1-12. https://doi.org/10.1080/1359432X.2016.1229307

Diefendorff, J. M., Erickson, R. J., Grandey, A. A., \& Dahling, J. J. (2011). Emotional display rules as work unit norms: a multilevel analysis of emotional labor among nurses. Journal of Occupational Health Psychology, 16(2), 170-186. https://doi.org/10.1037/a0021725

Djafri, F., \& Noordin, K. (2017). The impact of workplace spirituality on organizational commitment: a case study of Takaful agents in Malaysia. Humanomics, 33(3), 384-396. https://doi.org/10.1108/H-02-2017-0018

Dunbar, M., \& Baker, W. D. (2014). Teaching as emotional labor: preparing to interact with all students. Language Arts Journal of Michigan, 30(1).

Emmons, R. A. (2000a). Is spirituality an intelligence? motivation, cognition, and the psychology of ultimate concern. International Journal for the Psychology of Religion, 10(1), 3-26. https://doi.org/10.1207/S15327582IJPR1001_2

Emmons, R. A. (2000b). Spirituality and intelligence: Problems and propects. The International Journal for the Psychology of Religion, 10(1), 57-64. https://doi.org/10.1207/S15327582IJPR1001

Faribors, B., Fatemeh, A., \& Hamidreza, H. (2010). The relationship between nurses' spiritual intelligence and happiness in Iran. Procedia - Social and Behavioral Sciences, 5, 1556-1561. https://doi.org/10.1016/j.sbspro.2010.07.325

Fashi, F. M. (2017). Studying the relationship between spiritual intelligence of nurses and patients' satisfaction with nursing care. Bali Medical Journal, 6(3), 539-542. https://doi.org/10.15562/bmj.v6i3.542

Firuzjaeyan, A. A., Firuzjaeyan, M., \& Sadeghi, B. (2015). A survey of the effect of organizational culture on organizational commitment based on Allen and Meyer model (Case study: High school teachers of Bandpey region ). International Journal of Academic Research in Businnes and Socail Sciences, 5(1), 1-9. https://doi.org/10.6007/IJARBSS/v5-i1/1394

Fontaine, R. (2018). Developing spiritual intelligence: Some new evidence. International Journal of Islamic Management and Business, 7(1), 95-107.

Frost, M. H., Reeve, B. B., Liepa, A. M., Stauffer, J. W., Hays, R. D., \& Mayo, F. P. M. C. (2007). What is sufficient evidence for the reliability and validity of patient-reported outcome measures? Value in Health, 10(Supplement 2), 94-105. 
Fry, L. W., Latham, J. R., Clinebell, S. K., \& Krahnke, K. (2016). Spiritual leadership as a model for performance excellence: A study of Baldrige award recipients. Journal of Management, Spirituality \& Religion, 6086(July), 1-27. https://doi.org/10.1080/14766086.2016.1202130

Gabriel, A. S., Daniels, M. A., Diefendorff, J. M., \& Greguras, G. J. (2015). Emotional labor actors: a latent profile analysis of emotional labor strategies. Journal of Applied Psychology, 100(3), 863-879.

Gardner, H. (1993). Multiple intelligences: The theory in practice. New York: Basic Books.

Gardner, H. (1995). Reflections on multiple intelligencies: Myths and Messages. The Phi Delta Kappan, 77(3), 200-209.

George, M. (2006). Practical application of spiritual intelligence in the workplace. Human Resource Management International Digest, 14(5), 3-5.

Ghadi, M. Y. (2017). The impact of workplace spirituality on voluntary turnover intentions through loneliness in work. Journal of Economic and Administrative Sciences, 33(1), 81-110. https://doi.org/10.1108/JEAS-03-2016-0005

Giacalone, R. A., \& Jurkiewicz, C. L. (2010). Handbook of workplace spirituality and organizational performance (2nd ed.). New York: M. E. Sharpe, Inc.

Grandey, A. A., Diefendorff, J. M., \& Rupp, D. E. (2013). Emotional Labor in the 21 st Century Diverse Perspectives. New York: NY: Routledge.

Grandey, A. A., Rafaeli, A., Ravid, S., Wirtz, J., \& Steiner, D. D. (2010). Emotion display rules at work in the global service economy: the special case of the customer. Journal of Service Management, 21(3), 388-412. https://doi.org/10.1108/09564231011050805

Grandey, A. A., Rupp, D. E., \& Brice, W. (2015). Emotional labor threatens decent work: A proposal to eradicate emotional display rules. Journal of Organizational Behavior, 36, 770-785. https://doi.org/10.1002/job

Grandey, A. A., \& Sayre, G. M. (2019). Emotional labor: Regulating emotions for a wage. Current Directions in Psychological Science, 1-7. https://doi.org/10.1177/0963721418812771

Guillemin, F., Bombardier, C., \& Beaton, D. (1993). Cross-cultural Adaptation of Healthrelated quality of life measures: Literature review and proposed guidelines. Journal of Clinical Epidemiology, 46(12), 1417-1432.

Hagenauer, G., \& Volet, S. E. (2014). "“I don" t hide my feelings, even though I try to": Insight into teacher educator emotion display. The Austrialian Educational Researcher, 41, 261-281. https://doi.org/10.1007/s13384-013-0129-5

Hair, J. F. (Jr)., Black, W. C., Babin, B. J., \& Anderson, R. E. (2010). Multivariate data analysis (7th ed.). New Jersey: Prentice Hall.

Hochschild, A. R. (1983). The Managed heart: commercialization of human feeling. Barkeley, CA: University of California Press.

Hochschild, A. R. (2012). The Managed heart: commercialization of human feeling (2nd ed.). Barkeley, CA: University of California Press.

Hofmann, V., \& Stokburger-Sauer, N. E. (2017). The impact of emotional labor on employees' work-life balance perception and commitment: A study in the hospitality industry. International Journal of Hospitality Management, 65, 47-58. https://doi.org/10.1016/j.ijhm.2017.06.003 
Houston, G. G. (2014). Spirituality and leadership: Integrating spirituality as a developmental approach of improving overall leader effectiveness. Dissertation Abstracts International Section A: Humanities and Social Sciences, 76(6-A(E)). Retrieved from http://aura.antioch.edu/etds/87\%0Ahttp://search.ebscohost.com/login.aspx?direct=true \& $\mathrm{db}=$ psyh \&AN=2015-99230-520\&site=ehost-live

Hülsheger, U. R., Lang, J. W. B., Schewe, A. F., \& Zijlstra, F. R. H. (2015). When regulating emotions at work pays off: A Diary and an intervention study on emotion regulation and customer tips in service jobs. Journal of Applied Psychology, 100(2), 263-277.

Indregard, A. R., Knardahl, S., \& Nielsen, M. B. (2018). Emotional dissonance , mental health complaints, and sickness absence among health- and social workers. The moderating role of self-efficacy. Frontiers in Psychology, 9(592), 1-9. https://doi.org/10.3389/fpsyg.2018.00592

Jung, H. S., \& Yoon, H. H. (2016). Why is employees' emotional intelligence important? International Journal of Contemporary Hospitality Management, 28(8), 1649-1675. https://doi.org/10.1108/IJCHM-10-2014-0509

Kaiser, H. F. (1974). An index of factorial simplicity. Psychometrika, 39(1), 31-36.

Karatepe, O. M., \& Olugbade, O. A. (2009). The effects of job and personal resources on hotel employees ' work engagement. International Journal of Hospitality Management, 28, 504-512. https://doi.org/10.1016/j.ijhm.2009.02.003

Kaur, S., \& Malodia, L. (2017). Influence of emotional labour on job satisfaction among employees of private hospitals: a structural equation modelling approach. Journal of Health Management, 19(3), 1-18. https://doi.org/10.1177/0972063417717899

Khaliq, A., \& Ogunsola, O. K. (2011). An empirical assessment of Islamic leadership principles. International Journal of Commerce and Management, 21(3), 291-318. https://doi.org/10.1108/10569211111165325

Kim, M. J., \& Han, S. Y. (2009). Relationship between emotional labor consequences and employees' coping strategy. Asia Pacific Journal of Tourism Research, 14(3), 225-239. https://doi.org/10.1080/10941660903023929

King, D. B. (2008). Rethinking claims of spiritual intelligence: A definition, model and measure. Unpublished Master's Thesis. Trent University, Peterborough, Ontario, Canada.

King, D. B., \& DeCicco, T. L. (2009). A Viable model and self-report measure of spiritual intelligence. International Journal of Transpersonal Studies, 28(1), 68-85.

Kinman, G., Wray, S., \& Strange, C. (2011). Emotional labour, burnout and job satisfaction in UK teachers: the role of workplace social support. Educational Psychology: An International Journal of Experimental Educational Psychology, 31(7), 843-856. https://doi.org/10.1080/01443410.2011.608650

Kline, R. B. (2011). Principles and practice of structural equation modeling (3rd ed.). New York, NY: The Guildford Press.

Kulshrestha, S., \& Singhal, T. K. (2017). Impact of spiritual intelligence on performance and job satisfaction: A study on school teachers. International Journal of Human Resource \& Industrial Research, 4(2), 1-6. https://doi.org/10.5281/zenodo.343742

Kumari, M., \& Chahal, D. (2017). Spiritual intelligence of secondary school teachers in relation to their demographic variables. International Journal of Academic Research and 
Development, 2(4), 462-465.

Kwok, K. T. (2011). Emotional labor of teaching. Educational Research, 2(8), 1312-1316.

Lee, Y. H. (2017). Emotional labor, teacher burnout, and turnover intention in high-school physical education teaching. European Physical Education, 1-18. https://doi.org/10.1177/1356336X17719559

Ling, C. S. (2017). When teachers who punish are punished. Retrieved September 19, 2018, from https://www.nst.com.my/news/2017/03/219611/when-teachers-who-punish-arepunished

Liu, J., \& Cho, S. (2018). Interaction effect of display rules and emotional intelligence on hotel managers' and non-mangers' work engagement. International Journal of Contemporary Hospitality Management, 30(3), 1903-1919. https://doi.org/http://dx.doi.org/10.1108/MRR-09-2015-0216

Mafukata, M. A., \& Mudau, A. V. (2016). Exploring teacher mass resignation and early retirement from public schools. Dirasat, Human and Social Sciences, 43, 2243-2255.

Mahmood, A., Arshad, M. A., Ahmed, A., Akhtar, S., \& Khan, S. (2018). Spiritual intelligence research within human resource development: A thematic review. Management Research Review, 41(8), 987-1006. https://doi.org/10.1108/MRR-032017-0073

Mamman, A., \& Zakaria, H. B. (2016). Spirituality and Ubuntu as the foundation for building African institutions, organizations and leaders. Journal of Management, Spirituality and Religion, 13(3), 246-265. https://doi.org/10.1080/14766086.2016.1159976

Mann, S. (1997). Emotional labour in organizations. Leadership \& Organization Development Journal, 18(1), 4-12. https://doi.org/10.1108/01437739710156231

Mann, S., \& Cowburn, J. (2005). Emotional labour and stress within mental health nursing. Journal of Psychiatric and Mental Health Nursing, 12(2), 154-162. https://doi.org/10.1111/j.1365-2850.2004.00807.x

Mariesa, H. A., \& Rockoff, J. E. (2012). Worker absence and productivity: Evidence from teaching. Journal of Labor Economics, 30(4), 749-782.

Mark, B. W. (2010). The effectiveness of a gaze cue depends on the facial expression of emotion: Evidence from simultaneous competing cues. Attention, Perception \& Psychophysic, 72(7), 1814-1824. https://doi.org/10.3758/APP

Marsh, H. W., \& Hocevar, D. (1985). Application of confirmatory factor analysis to the study of self-concept: First- and higher order factor models and their invariance across groups. Psychological Bulletin, 97(3), 562-582.

Maslow, A. H. (1943). A theory of human motivation. Psychological Review, 50(4), 370396. https://doi.org/10.1037/h0054346

Milliman, J., \& Bradley-geist, J. C. (2017). The implications of workplace spirituality for person - environment fit theory. Psychology of Religion and Spirituality, 9(1), 1-12.

Mishra, S. K., \& Kumar, K. K. (2016). Minimizing the cost of emotional dissonance at work: a multi-sample analysis. Management Decision, 54(4), 778-795. https://doi.org/10.1108/MD-06-2015-0222

Naik, A. R., \& Jabeen, K. (2019). Yoga as an important aspect for spiritual intelligence. International Journal of Advance and Innovative Research, 6(1), 66-70.

Näring, G., Briët, M., \& Brouwers, A. (2007). Validation of the Dutch Questionnaire on 
emotional labour (D-QEL) in nurses and teachers. Psychosocial Resources in Human Services Work, 135-145.

Nasel, D. D. (2004). Spiritual orientation in relation to spiritual intelligence: A consideration of traditional Christianity and New Age/individualistic spirituality. Unpublished doctoral dissertation, University of South Australia.

Nauman, S., Raja, U., Haq, I. U., \& Bilal, W. (2019). Job demand and employee well-being: A moderated mediation model of emotional intelligence and surface acting. Personnel Review, 1-20. https://doi.org/10.1108/PR-04-2018-0127

Nunnally, J. C. (1978). Psychometric theory. New York: McGraw-Hill.

Ogunsola, K. O. (2018). Servant leadership: Developing an Islamic performance appraisal instrument for Muslim managers. Malaysian Management Review, 53(1), 55-76.

Ogunsola, K. O., Fontaine, R. A., \& Jan, M. T. (2020a). A cross-cultural adaptation and psychometric validation of SISRI-24 among Malaysian Teachers. International Journal of Human Potentials Management, 2(1), 1-22. https://doi.org/10.14738/assrj.610.7243

Ogunsola, K. O., Fontaine, R. A., \& Jan, M. T. (2020b). Impact of surface acting and deep acting techniques on teachers' organizational commitment. PSU Research Review. https://doi.org/10.1108/PRR-10-2019-0031

Okabe, N. (2020). Employee Satisfaction, Task Performance, and Emotional Labor: An Empirical Examination. Springer International Publishing. https://doi.org/10.1007/9783-030-20145-6

Osman-Gani, A., Anwar, M. A., \& Hamid, Z. A. (2017). Impacts Of Emotional Intelligence And Spiritual Intelligence On Leadership Effectiveness Mediated By Personal Values: A Conceptual Framework. Journal of Islamic Management Studies, (1), 43-53. Retrieved from http://publications.waim.my/index.php/jims/article/view/7

Osman-Gani, A. M., \& Hassan, Z. (2018). Impact of spiritual and cultural intelligence on leadership effectiveness: a conceptual analysis. Journal of Islamic Management Studies, 2(1), 12-23. https://doi.org/10.24961/j.tek.ind.pert.2018.28.1.61

Othman, A. K., \& Abas, M. K. (2017). The moderating role of spiritual intelligence on the relationship between job stress and job performance of employees in abanking sector. Journal of Islamic Management Studies, 1(1), 89-103.

Pallant, J. (2007). SPSS survival manual: A step-by-step guide to data analysis using SPSS for Windows (version 15) (3rd ed.). Australia, Allen \& Unwin.

Pant, N., \& Srivastava, S. K. (2017). The Impact of spiritual intelligence, gender and educational background on mental health among college students. Journal of Religion and Health, 1-22. https://doi.org/10.1007/s10943-017-0529-3

Pillay, R., Flotman, A.-P., \& Mitonga-monga, J. (2019). Emotional labour among Women Leaders within the South African Consulting Industry: A Hermeneutic Phenomenological Inquiry. Southern African Business Review, 23, 1-23. https://doi.org/10.25159/1998-8125/4280

Prentice, C. (2014). Emotional labour and its consequences: the moderating effect of emotional intelligence. Research on Emotion in Organizations, 9(Sep), 187-201. https://doi.org/10.1108/S1746-9791(2013)9

Putnam, L. L., \& Mumby, D. K. (1993). Organizations, emotion and the myth of rationality. In S. Fineman (Ed.), Emotion in Organizations. London: Sage. 
Rafaeli, A., \& Sutton, R. I. (1987). Expression of emotion as part of the Work Role. The Academy of Management Review, 12(1), 23-37.

Rahman, Z. A., \& Shah, I. M. (2015). Measuring Islamic spiritual intelligence. Procedia Economics and Finance, 31(15), 134-139. https://doi.org/10.1016/S22125671(15)01140-5

Ramachandaran, S. D., Krauss, S. E., Hamzah, A., \& Idris, K. (2017). Effectiveness of the use of spiritual intlligence in women academic leadership practice. International Journal of Educational Management, 31(2). https://doi.org/http://dx.doi.org/10.1108/MRR-092015-0216

Richard, E. M., Bupp, C. P., \& Alzaidalsharief, R. G. (2016). Supervisor empathy moderates the negative effects of customer injustice. Emotions and Organizational Governance., 12, 117-140. https://doi.org/10.1108/S1746-979120160000012004

Richard, E. M., \& Converse, P. D. (2016). An examination of within-person variance in contextual display rules and deviation from display rules. European Journal of Work $\begin{array}{lll}\text { and Organizational } & \text { Psychology, 25(3), 412-429. }\end{array}$ https://doi.org/10.1080/1359432X.2015.1102133

Ron, D. H., Honghu, L., \& Arie, K. (2015). Use of internet panels to conduct surveys. Behavioral Research Methods, 47(July), 685-690. https://doi.org/10.3758/s13428-0150617-9

Roof, R. A., Bocarnea, M. C., \& Winston, B. E. (2017). The spiritual engagement instrument. Asian Journal of Business Ethics. https://doi.org/10.1007/s13520-017-0073-y

Roth, G., Benita, M., Amrani, C., Shachar, B., Asoulin, H., Moed, A., \& Bibi, U. (2014). Integration of negative emotional experience versus suppression: Addressing the question of adaptive functioning. Emotion, 14(5), 908-919.

Ruppel, C. P., Sims, R. L., \& Zeidler, P. (2013). Emotional labour and its outcomes: A study of a Philippine call centre. Asia-Pacific Journal of Business Administration, 5(3), 246261. https://doi.org/10.1108/APJBA-02-2013-0008

Safdar, S., Friedlmeier, W., Matsumoto, D., Yoo, S. H., Kwantes, C. T., Kakai, H., \& Shigemasu, E. (2009). Variations of emotional display rules within and across cultures: A comparison between Canada, USA, and Japan. Canadian Journal of Behavioural Science, 41(1), 1-10. https://doi.org/10.1037/a0014387

Santos, A., Mustafa, M. J., \& Gwi, T. C. (2015). Trait emotional intelligence, emotional labour, and burnout among malaysian HR professionals. Management Research Review, 38(1), 67-88. https://doi.org/10.1108/MRR-06-2013-0143

Saremi, H., \& Rajab, M. (2015). A study on the relationship between spiritual intelligence and organizational commitment for male teachers at elementary schools in academic year of 2013-2014, in Quchan City, Iran. International Journal of Life Sciences, 9(6), 24-32.

Schermerhorn, J. R. (Jr)., Hunt, J. G., Osborn, R. N., \& Uhl-Bien, M. (2011). Organizational behavior (11ed ed.). Asia: Wiley.

Schirmer, A., \& Adolphs, R. (2017). Emotion perception from face, voice, and touch: comparisons and convergence. Trends in Cognitive Sciences, 21(3), 216-228. https://doi.org/10.1016/j.tics.2017.01.001

Schumacker, R. E., \& Lomax, R. G. (2012). A beginner's guide to structural equation 
modeling (3rd ed.). Taylor \& Francis.

Sekaran, U. (2003). Research methods for business: a skill building approach (4th ed.). John Wiley \& Sons, Inc.

Sisk, D. A. (2015). Spiritual intelligence: developing higher consciousness revisited. Gifted Education International, 32(3), 1-15. https://doi.org/10.1177/0261429415602567

Soha, M. H., Osman, A., Nizam, S., Abdullah, S., \& Ramlee, N. F. (2016). The relationship of work influence, sense of community and individual spirituality towards organizational performance. Procedia Economics and Finance, 35(October), 591-596. https://doi.org/10.1016/S2212-5671(16)00072-1

Solomon, R. C. (2002). Back to basics: on the very idea of "Basic Emotions ." Journal for the Theory of Social Behaviour, 32(2), 115-144.

Tabachnick, B. G., \& Fidell, L. S. (2007). Using multivariate statistics (5th ed.). Boston: Pearson Education.

Tsang, S., Royse, C. F., \& Terkawi, A. S. (2017). Guidelines for developing, translating, and validating a questionnaire in perioperative and pain medicine. Saudi Jounal of Anaesthesia, 11(1), 1-15. https://doi.org/10.4103/sja.SJA_203_17

Upadhyay, S. (2017). Can spiritual intelligence influence research performance in higher education? Framework for human resource development in higher education. Administratie Si Management Public, 28, 153-173.

Vaughan, F. (2002). What is spiritual intelligence? Journal of Humanistic Psychology, 42(2), 16-33. https://doi.org/10.1177/0022167802422003

Walsh, G., \& Bartikowski, B. (2013). Employee emotional labour and quitting intentions: moderating effects of gender and age. European Journal of Marketing, 47(8), 12131237. https://doi.org/10.1108/03090561311324291

Walsh, G., Yang, Z., Dahling, J., Schaarschmidt, M., \& Takahashi, I. (2019). Effects of service employees ' negative personality traits on emotional labour and job satisfaction Evidence from two countries. Management Decision, 1-19. https://doi.org/10.1108/MD11-2018-1206

Wang, M., Han, Y., \& Su, Y. (2017). Social contagion or strategic choice?: The nterpersonal effects of emotions during chinese negotiations. Chinese Management Studies, 11(3), 463-478. https://doi.org/10.1108/CMS-05-2017-0122

Weiss, H. M., \& Cropanzano, R. (1996). Affective events theory: a theoretical discussion of the structure, causes and consequences of affective expereinces at work. Research in Organizational Bahavior, 18, 1-74.

Wigglesworth, C. (2006). Why spiritual intelligence is essential to mature leadership. Integral Leadership Review, 6(3). Retrieved from http://integralleadershipreview.com/5502-feature-article-why-spiritual-intelligence-isessential-to-mature-leadership/

Yagil, D. (2015). Display rules for kindness: outcomes of suppressing benevolent emotions. Motivation and Emotion, (39), 156-166. https://doi.org/10.1007/s11031-014-9418-1

Yahyazadeh, J. S., \& Fatemeh, L.-G. (2012). What Is the relationship between spiritual Intelligence and Job satisfaction among MA and BA Teachers? International Journal of Business and Social Science, 3(8), 299-303.

Yilmaz, K., Altinkurt, Y., Guner, M., \& Şen, B. (2015). The relationship between teachers' 
emotional labor and burnout level. Eurasian Journal of Educational Research, (59), 7590.

Yin, H., Huang, S., \& Lee, J. C. K. (2017). Choose your strategy wisely: Examining the relationships between emotional labor in teaching and teacher efficacy in Hong Kong primary schools. Teaching and Teacher Education, 66, 127-136. https://doi.org/10.1016/j.tate.2017.04.006

Yu-Shan, (Sandy) Huang, \& Tom, J. B. (2016). How does customer orientation influence authentic emotional display? Journal of Services Marketing, 30(3), 316-326. https://doi.org/10.1108/JSM-12-2014-0402

Zainudin, A. (2014). A handbook on SEM for academicians and practitioners. The step by step practical guides for the beginners. Selangor: MPWS Rich Resources.

Zapf, D. (2002). Emotion work and psychological well-being: A review of the literature and some conceptual considerations. Human Resource Management Review, 12, 237-268.

Zohar, D., \& Marshall, I. (2000). SQ-Spiritual Intelligence: The ultimate intelligence. London: Bloomsbury Publishing.

Zou, W., \& Dahling, J. (2017). Workplace spirituality buffers the effects of emotional labour on employee well-being. European Journal of Work and Organizational Psychology, 110. https://doi.org/10.1080/1359432X.2017.1358164 